Sains Malaysiana 49(6)(2020): 1351-1358

http://dx.doi.org/10.17576/jsm-2020-4906-13

\title{
Role of Novel Therapeutic Agents in Modulating Invadopodia Formation in Metastatic Breast Cancer
}

(Peranan Agen Terapi Baru dalam Memodulasikan Pembentukan Invadopodia dalam Kanser Payudara Metastatik)

\author{
Siti Nor Aini Harun, Nurul Akmaryanti Abdullah, Noraina Muhamad Zakuan, Hafizah AbDul

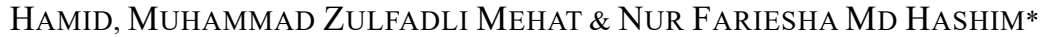

\begin{abstract}
The ability to colonize distant organs which is lethal has made metastatic breast cancer become the top ten causes of mortality worldwide. Specialized actin-rich protrusions termed invadopodia were thought to be formed by highly invasive cells to degrade the extracellular matrix to drive cancer invasion and metastasis. Identification of compound(s) to hinder the formation ofinvadopodia is important to resist the metastasis of breast cancer as well as to yield antimetastasis targeted therapy. The current review aims to provide new insights on cancer invasion and candidate compound(s) capable to disrupt invadopodia formation and invadopodia-related proteins.
\end{abstract}

Keywords: Cancer invasion; invadopodia; metastatic breast cancer

ABSTRAK

Keupayaan untuk merebak ke organ lain telah menjadikan kanser payudara metastatik antara puluhan penyebab kematian di seluruh dunia. Protusi khusus diperkaya-aktin ataupun invadopodia dikatakan terbentuk daripada selsel yang invasif sehingga mendegradasi matriks ekstrasel yang seterusnya mendorong kepada serangan kanser dan metastasis. Pengenalpastian kompaun untuk menghalang pembentukan invadopodia adalah penting untuk menentang kanser payudara metastatik serta mencari terapi sasaran anti-metastatik. Ulasan ini bertujuan untuk memberikan pandangan baru mengenai serangan kanser dan kompaun yang berkemungkinan menghalang pembentukan invadopodia dan protein berkaitan dengan invadopodia.

Kata kunci: Invadopodia; kanser payudara metastatik; serangan kanser

\section{INTRODUCTION}

Breast cancer incidences in Malaysia has recorded 31.1\% cases from 2007-2011 which precede other cancer cases (Azizah et al. 2015). Breast cancer is widely recognized to disseminate toother parts of the body known as cancer metastasis (Scully et al. 2012) and it is also one of the hallmarks of cancer (Hanahan \& Weinberg 2011). Triple negative breast cancer (TNBC) is characterized by negative expression of estrogen receptor, progesterone receptor and HER2 (human epidermal growth factor receptor 2). TNBC is often associated with poor prognosis and higher death rate (Anders \& Carey 2008). Metastatic breast cancer patients frequently confront relapse after receiving the treatments indicating the failure of primary therapy (Dent et al. 2007). Since current treatments are also producing side effects and have promoted metastasis and recurrence, chemoprevention study by the examination of new compounds or drugs should be enthusiastically done (Weigelt et al. 2005). The first part of this review will discuss on the metastatic cascade and the proteins related to invadopodia and cancer invasion. The later part of the review will focus on the possible compound(s) that may target invadopodia-related proteins to delay breast cancer metastasis.

\section{METASTATIC CASCADES}

Metastasis is one of the life-threatening events occurred among cancer patients (Steeg 2016). The concept of metastasis has been proposed since 1889 by Stephen Paget with the theory of seed and soil to define the journey of cancer dissemination (Paget 1889). Metastasis has been postulated that it does not occur by chance but the cancer cells ('seed') need to be well-matched with the organ of interest ('soil') then only the metastatic cancer cells can populate the new 'home' (Paget 1889). Study on cancer metastasis evolves with the findings that this process requires mechanical factors and the heterogeneity of the metastasis itself have caused the cancerto be difficult to be treated (Massagué et al. 2017). Cancer metastasis consists of several chronological steps which are interrelated to each other (Massagué et al. 2017). The tumor cells need to break away from the primary tumor to metastasize (Mendonsa et al. 2018). The acquisition of escaping from the primary tumor 
happened due to the altered adhesion; loss of E- cadherin which initiate the tumor to detach from the primary site to proceed to malignancy (Riggi et al. 2018). The cells will then migrate and invade into the surrounding tissues which consist of dense meshwork of extracellular matrix (ECM) and adhere to the basement membrane of the lymphatic or blood vessels before degrading the membrane again to intravasate to the blood circulation and/or lymphatic system (Cheung \& Ewald 2016). Still, to reside to the new microenvironment, the cancer cells needs to fight with the immune cells and cell death signals (Cheung \& Ewald 2016). Only less than 0.01\% of invasive cancer cells are able to survive the new microenvironment and metastasize after their long circulating journey (Langley \& Fidler 2011).

\section{MIGRATION AND INVASION}

One of the hallmark of cancer metastasis is the spreading ability of tumor cells by the process of migration and invasion (Poste \& Fidler 1980). Cell invasion involves three key steps which are the detachment of tumor cells from the primary tumor site, production of proteolytic enzymes to drive matrix dissolution and cell migration (Liotta et al. 1991). As stated previously, loss of cell-cell contact has initiated the migratory ability of the tumor cells with the release of proteases to aid the way to the blood vessels (Liotta et al. 1991). Cell migration involves the reorganization of the cytoskeleton to aid cell motility. The direction of the cells motion is pointed to the source of angiogenesis stimulus (Liotta et al. 1991). The cytoskeletal proteins implicated in cell motilityare divided into three types which are microtubules, intermediate filaments, and actin filaments (also known as microfilaments) (Jiang et al. 2009). In breast cancer, the actin cytoskeleton has been found to regulate the dynamic cell motility (Pollard \& Borisy 2003). The actin filaments are structured into three-dimensional (3D) networks that form either lamellipodia, filopodia and/ or invadopodia in cancer cells (Chhabra \& Higgs 2007). Lamellipodia are observed as protrusions at the leadingedge during cell movement, while filopodia are highly dynamic extension of the plasma membrane.

Invadopodia refers to the extension established by the F-actin that cross-linked into a network and used for invasion through the extracellular matrix (Chhabra \& Higgs 2007). The family members of Rho GTPases including Rac, Rho and $\mathrm{Cdc} 42$ are the regulators that are well-studied for cell migration. Once the Rho GTPases are activated, these will lead to the assembly of actin-myosin contractile filaments into focal adhesion complexes which then promote the cell polarity and migration (Hall 1998). The migration of tumor cells has been studied in 2D culture systems and recently in three-dimensional (3D) culture systems (Doyle et al. 2013). Initially, the 2D method has been established to explain the concept of cell migration and their adhesion onto the flat surface (Doyle et al. 2013). This method has guided the researchers to find out the molecular pathways involved. However, as the studies continued, the presence of ECM can also control and modulate the migration of the cancer cells which then lead the studies to use $3 \mathrm{D}$ culture system with addition of matrix to the model thus the invasive characteristics of cancer cells can also be investigated (Doyle et al. 2013). Moreover, the $3 \mathrm{D}$ model introduced to study cell migration is also mimicking the in vivo model thus, the molecular targets linked to cancer migration can also be scientifically investigated (Doyle et al. 2013).

Among the targets that are found by using the 3D experimental design are $\mathrm{Cdc} 42$, Rac1, and RhoA and the signaling proteins found are also associated with the presence of ECM (Doyle et al. 2013). Continuous studies have also reported tumor cells that migrate and invade the ECM form specialized protrusions which are called invadopodia (Artym et al. 2006; Bravo-Cordero et al. 2012; Gligorijevic et al. 2012). Migration and invasion are interrelated to each other as the cancer cells committed to both steps to detach from the origin of the tumor and continue to the subsequent growth at the new organ(s) (Sahai 2005). Application of therapies to prevent the migration and invasion are useful strategies to reduce the dissemination of tumor cells however, understanding the mechanisms and factors that promote the motility of the cancer cells should be prioritized (Sahai 2005).

\section{INVADOPODIA}

For the cancer cells to move into the distant parts of the body, researchers thought that the highly invasive cancer cells form 'invasive feet' known as invadopodia (Buccione et al. 2004). Invadopodia; specialized membrane protrusions which rich in actin cytoskeleton that extend into the ECM is thought to be the first step employed by the cancer cells to degrade the ECM and drive cancer invasion (Buccione et al. 2004). The cell-ECM contact structures has been first discovered in chicken embryonic fibroblasts transformed with the Rous Sarcoma Virus (RSV) oncogene v-Src (David-Pfeuty \& Singer 1980). Later, these structures which contain actin-rich cores (Tarone et al. 1985) are described as podosomes. However, at the last stage of the discovery, when the cells are not only involved in cell-ECM contacts and adhesion but also having the potential to degrade the ECM to invade into surrounding tissues, the term invadopodia has been introduced (Chen 1989). Both podosomes and invadopodia are two terms used to characterize the protrusions that are being formed by the cells (Murphy \& Courtneidge 2011). Meanwhile, podosomes have been shown to not only being formed in the cultured osteoclasts but also in other types of cells which include highly invasive normal cells; macrophages and dendritic cells, endothelial cells and vascular smooth 
muscle cells (Zambonin et al. 1988). Invadopodia and podosomes require Src kinase and actin assembly as well as focal adhesion proteins, integrins, and proteases to form the protrusions and degrade ECM (Linder \& Aepfelbacher 2003). In 2D gelatin degradation assay, invadopodia is recognized as actin-rich dots stained with fluorochrome dye which co-localized with black puncta or dots on gelatin or other extracellular matrix such as fibronectin and collagen which indicate the degradation area. In 3D experiment, the structure of invadopodia is more complex as the cells are growing comfortably like in a tumor microenvironment (Tolde et al. 2010; Wang et al. 2016). In a study by Tolde et al. (2010), the data showed that there is distinct characteristic of invadopodia formed in $2 \mathrm{D}$ culture and in the dermisbased $3 \mathrm{D}$ matrix. It has been shown that invadopodia which are formed in the 3D matrix have produced more prominent $\mathrm{F}$-actin rich protrusions compared to invadopodia on thin matrix (2D culture). It is believed that cells cultured in $3 \mathrm{D}$ matrix are mimicking the in vivo condition and this would allow invadopodia to be introduced in a more physiological surrounding (Tolde et al. 2010). Meanwhile, A549 lung cancer cells cultured in $3 \mathrm{D}$ microfluidic device have also been demonstrated to appear more circular compared to $2 \mathrm{D}$ culture and the protrusions of invadopodia are more noticeably formed as the condition is physiologically mimicking the microenvironment of the tumor (Wang et al. 2013). There are several models of studying invadopodia in vivo such as by conducting the experiment in mouse tumor models, zebrafish. Intestinal epithelia and Caenorhabditis elegans organogenesis (Lohmer et al. 2014). However, the challenges in studying invadopodia formation in vivo are the requirements for high-technology imaging systems to observe the 'feet' formation which are being used by the invasive cancer cells to invade into the surrounding tissues. Maybe with the findings of invadopodia in in vivo could be the kickstart to prove that these protrusions are to be a potential biomarker in cancer invasion in order to improve the prognosis in cancer patients (Lohmer et al. 2014).

\section{INVADOPODIA AND THEIR COMPONENTS}

Invadopodia are commonly found in highly invasive cancer cells and have been extensively studied in numerous cancer cell lines including lung (Wang et al. 2013), breast cancer and melanomas (Díaz et al. 2013; Md Hashim et al. 2013). There are plenty of studies being conducted in the past thirty years to study invadopodia associated protein driven, stimuli required for their formation, and applicability of in vivo study on invadopodia (Hoshinoet et al. 2013; Lohmer et al. 2014; Murphy \& Courtneidge 2011; Tolde et al. 2010). The proteins that are found in invadopodia can be separated into several classes which are actin regulated proteins; cortactin, Neural-Wiskott Aldrich Syndrome protein (N-WASP), actin-related proteins 2 and 3 (Arp 2/3) complex, WASP-interacting protein (WIP), cofilin, talin, fascin; signaling proteins; Cdc42, Nck1, Src, $\beta$-PIX; adhesion proteins; integrins, vinculin, paxillin, ezrin; proteases; matrix metalloproteinases-9 (MMP-9) and membrane type 1-MMP (MT1-MMP) (Hoshino et al. 2013)

\section{Protein for actin regulations}

F-actin is thought to be the biomarker for invadopodia and commonly stained in invadopodia formation study (Md Hashim et al. 2013). Cortactin, N-WASP, Arp 2/3 complex, WIP, cofilin, fascin, and talin are the proteins that are required for the regulation and stabilization of actin (Ridley 2015). Cortactin is an essential protein that promotes the nucleation of actin (Shen et al. 2015). Cortactin has been first recognized as Src kinase substrate which can be found at the sub- membranous zone (Schnoor et al. 2017). The genes encode cortactin is CTTN gene and this gene is situated in a chromosomal region 11q13 (Schnoor et al. 2017). Recent studies demonstrated that even one mutation occurred on the structure of cortactin can cause the inability of the invadopodia to be formed which indicates each structure on cortactin is necessary for the tumor cells to form invadopodia (Shen et al. 2015).

\section{Signaling proteins}

To date, numerous growth factors have been pointed out to be working on the establishment of invadopodia formation (Hoshino et al. 2013) such as colony stimulating factor-1 (CSF1), platelet product transforming growth factor $\beta$ (TGF- $\beta$ ), vascular endothelial growth factor (VEGF), platelet-derived growth factor (PDGF), epidermal growth factor (EGF), heparin binding (HB)EGF), hepatocyte growth factor/scatter factor (HGF) and stromal cell derived factor $1 \alpha(\operatorname{SDF} 1 \alpha)$ (Hoshino et al. 2013). These growth factors share common signaling hubs especially Src kinase, phosphoinositide 3-kinases (PI3Ks) and Rho family GTPases, which ultimately control invadopodia and podosomes (Murphy \& Courtneidge 2011). Epidermal growth factor receptor (EGFR) has been proven to target Src kinase which later activates cortactin to drive invadopodia formation in breast cancer (Mader et al. 2011).

$\beta$-PIX is among the signaling protein that has been investigated to be associated in the formation of invadopodia as it is guanine nucleotide exchange factor for Rac and Cdc42 (Ridley 2015). The association of $\beta$-PIX and invadopodia formation has also been investigated in hypoxic background ( $\mathrm{Md}$ Hashim et al. 2013). The $\beta$-PIX expression level has been upregulated in the presence of hypoxia and $\beta$-PIX is shown to be required for invadopodia formation $(\mathrm{Md}$ Hashim et al. 2013). A study has also been conducted to check the relationship between $\beta$-PIX and also Src. The 
results showed that the recruitment of $\beta$-PIX resulted in the activation of the Rac protein in invadopodia (Gujam et al. 2014). Besides, the regulation of cell adhesion and migration is set out to be implied with the $\beta$-PIX protein (Kuo et al. 2011).

\section{PROTEASES}

Proteases are recruited to invadopodia to degrade the matrix. Among matrix metalloproteinase (MMP) which have been commonly found at invadopodia are MMP-2, MMP-9, MT1-MMP, and ADAM12 (Clark et al. 2007; Díaz et al. 2013). Previous study has reported the role of cortactin in the production of invadopodia-associated MMPs: MMP-2, MMP-9, and MT1-MMP (Artym et al. 2006). Remarkably, cortactin has been shown to inhibit MMPs which then decrease the invadopodia actin puncta formation (Artym et al. 2006). A more recent study has been conducted to observe the synergistic effect on blocking cancer invasion using computer simulations (Ichikawa 2015). The data has shown that blocking MT1MMPs alone; which are among the proteases that located at invadopodia is not enough but combination of several strategies to block MT1-MMPs could be possible ways to hinder invasion (Ichikawa 2015). Recently, a gene associated with the metastasis to bone in breast cancer which is Target of MYB1-like protein 1 (TOM1L1) (also known as Srcasm) has been recognized (Smid et al. 2006). This gene has been co-amplified with ERBB2 in breast cancer and is postulated to function as prooncogene (Orsetti et al. 2004). The TOM1L1 protein is an adaptor protein of the TOM1 family with postGolgi trafficking and signaling functions (Wang et al. 2010). The TOM1L1 protein has been demonstrated to promote ERBB2-induced cell invasion by increasing the formation of invadopodia in favor of the MT1-MMP trafficking to the plasma membrane (Chevalier et al. 2016). Further investigation showed that TOM1L1 has regulated the MT1-MMP and the underlying mechanism of MT1-MMP trafficking in ERBB2-transformed cells involved the RAB-7 protein (Chevalier et al. 2016).

\section{CANDIDATE COMPOUNDS TO INHIBIT INVADOPODIA}

\section{SAFFLOWER}

A Chinese medicine named safflower has been tested on the formation of invadopodia in MDA-MB-231 breast cancer cells in which a reduction in invadopodia formation was observed and it is believed due to the restructuring of the cytoskeleton ( $\mathrm{Fu}$ et al. 2016). In this study, the expression of matrix metalloproteinase-9 (MMP-9) and the phosphorylation of Src (p-Src) has been reduced after safflower treatment. It has been speculated that the reduction in the formation of invadopodia was partly due to the reduction of MMP-9 and p-Src (Fu et al. 2016).

\section{CURCUMIN}

Curcumin is an active compound in turmeric and was reported to exhibit anti-bacterial, anti- oxidant, antiinflammation and anti-cancer activities (Gupta et al. 2012; Lee et al. 2016). Previous studies demonstrated that curcumin exerts anti-invasive effects in human breast cancer cells via downregulation of the MMP-2 and up-regulation of tissue inhibitor of metalloproteinase (TIMP-1) (Di et al. 2003; Hassan \& Daghestani 2012; Shao et al. 2002). Besides, curcumin also inhibited the vascular endothelial growth factor (VEGF) and b-FGF (basic fibroblast growth factor) in ER-negative breast cancer cells thus reducing the tumor invasion (Shao et al. 2002). In MDA-MB-231 cells, treatment with curcumin inhibits cell proliferation and migration via NF- $\kappa \mathrm{B}$ pathway (Chiu \& Su 2009). In addition, curcumin suppressed the migration and invasion of the LPAinduced MCF-7 breast cancer cells via downregulation of RhoA/ROCK/MMPs pathway (Sun et al. 2016).

The Cdc42 protein is overexpressed in many cancer cells and involved in the formation of invadopodia. The suppression of $\mathrm{Cdc} 42$ protein by curcumin is reported through the inhibition of reorganization of F-actin (Chen et al. 2012). Silencing of $\mathrm{Cdc} 42$ has also reduced the expression of p-cofilin and p-PAK-1 and increased the expression of E-cadherin (Chen et al. 2012). The Racl protein is another molecule associated with cytoskeleton rearrangement, cell adhesion, transcriptional activation and formation of invadopodia (Ward et al. 2015). Curcumin has been demonstrated to inhibit Rac1 in 801D lung cancer cells and reduce the migration and invasion of Rac1 overexpressed cells. The MMP-2 and -9 and also PAK1 expressions are inhibited in the Rac1 overexpressed cells suggesting that curcumin inhibit the $801 \mathrm{D}$ lung cancer migration and invasion via Rac1/PAK1 pathway (Chen et al. 2014). In spite of all the findings associated with curcumin, the bioavailability problem that curcumin displayed has been questioned and has encouraged the researchers to attempt on alternatives to overcome the issue by synthesizing curcumin analogue as nanoparticle (Krausz et al. 2015; Tham et al. 2010).

\section{BHMC}

BHMC is curcumin analouge, known as 2,6-bis-(4hydroxyl-3methoxybenzylidine) cyclohexanone. The presence of the $\beta$-diketone moiety in curcumin caused it to be rapidly metabolized in the liver by aldo-keto reductase, therefore limiting its therapeutic benefits on various types of diseases (Anand et al. 2007). The phenolic $\mathrm{OH}$ group is shown to be crucial for its anti-oxidative effects (Koo et al. 2015). The BHMC is synthesized based on the parental structure by replacing the unstable $\beta$-diketone moiety with conjugated 
double bonds while preserving the phenolic $\mathrm{OH}$ group. As a curcuminoid analogue, BHMC has been studied in inflammation, sepsis and hyperalgesia (Ming-Tatt et al. 2013; Tham et al. 2010). Treatment with BHMC has shown to inhibit the pro-inflammatory cytokines and signaling pathways of inflammation as well as to protect lethal sepsis of the caecal-ligation puncture (CLP) model of severe sepsis (Tham et al. 2011). Besides, BHMC also exhibits anti-hyperalgesic effect in neuropathic pain model in mice (Ming-Tatt et al. 2013). Furthermore, BHMC treatment on murine $4 \mathrm{~T} 1$ breast cancer cells (Razak et al. 2017) reduced the number of mitotic cells in 4T1 challenged mice demonstrating the anti-cancer effects by BHMC. Besides, the study also reported a reduction of metastatic $4 \mathrm{~T} 1$ cells to the lung. The expression of MMP-9, TNF- $\alpha$ and NF- $\kappa$ B genes have been reduced in the BHMC treated mice in comparison to the non-treated group (Razak et al. 2017). Recently, the effect of BHMC on the invadopodia formation in MDA-MB-231 cells was carried out and the findings showed that BHMC was able to reduce the number of cells forming invadopodia (Harun et al. 2018). Additionally, BHMC was able to suppress the expression of invadopodia-related proteins such as MT1-MMP, MMP-9 and B-PIX (Harun et al. 2018). Hence, it would be interesting to evaluate the effect of BHMC on other possible targeted molecules that link invadopodia and BHMC in the search of a direct association of BHMC and the invasiveness of breast cancer.

\section{RUTHENIUM COMPLEXES}

Ruthenium ( $\mathrm{Ru}$ ) complexes, belong to the platinummetal group have been shown to exhibit anticancer activities against breast cancer (Bergamo et al. 2010; Scolaro et al. 2005; Wu et al. 2014). In 2010, Bergamo et al. reported that treatment with $\mathrm{Ru}$ compound (RM175) for two weeks resulted in a reduction in breast tumor growth by $50 \%$ when compared to untreated control. This study also reported a reduction in secondary lung metastasis. The anti-metastatic effects of RM175 were shown to be mediated via the inhibition in MMP-2 production (Bergamo et al. 2010). RAWQ11 is a novel $\mathrm{Ru}$ complex agent found to inhibit invadopodia formation via inhibition in the AKT signaling pathway and upregulation of PTEN expression in MDA-MB-231 breast cancer cells (Wu et al. 2014). Treatment with RAWQ11 decreased the expression of MMP-2 and MMP9 in MDA-MB-231 cells (Wu et al. 2014). The potential compounds targeting invadopodia-related proteins that we describe in this review are summarized in Table 1.

TABLE 1. Summary proteins involved in invadopodia formation and maturation including potential compounds being studied

\begin{tabular}{lcc}
\hline Invadopodia-targeted proteins & Functions & Candidature compounds being investigated \\
\hline phospho-Src (p-Src) & $\begin{array}{c}\text { Promotes invadopodia formation } \\
\text { (Balzer et al. 2010) }\end{array}$ & Safflower (Fu et al. 2016)
\end{tabular}

MMP-2

MMP-9

MT1-MMP

$\beta$-PIX

$\operatorname{Cdc} 42$

TNF- $\alpha$

$\mathrm{NF}-\kappa \mathrm{B}$
Involves in collagen and gelatin degradation and promotes angiogenesis (Egeblad \& Werb 2002)

Collagen degradation and promotes angiogenesis (Egeblad \& Werb 2002)

Promotes degradation of ECM (Miyazawa et al. 2013)

Involves in activation of Rac protein in invadopodia (Gujam et al. 2014)

Involves in invadosome formation

(Di Martino et al. 2014)

Promotes cell migration and invasion

(Razak et al. 2017)

Control cell survival and promotes tumor angiogenesis

(Neil \& Schiemann 2008; Tang et al. 2017)
Curcumin (Shao et al. 2002) RAWQ11 (Wu et al. 2014)

Safflower (Fu et al. 2016) BHMC

(Harun et al. 2018; Razak et al. 2017) RAWQ11 (Wu et al. 2014)

BHMC (Harun et al. 2018)

BHMC (Harun et al. 2018)

Curcumin (Chen et al. 2012)

BHMC (Razak et al. 2017)

Curcumin (Chiu \& Su 2009)

BHMC (Razak et al. 2017) 


\section{CONCLUSION}

Invadopodia are believed to be the architect to drive cancer invasion. With the proteins related to invadopodia to be investigated thoroughly, we may also have a kick start to investigate the candidature compound(s) that may hit the invadopodia-targeted proteins as to hinder breast cancer invasion. The findings of the investigation might be valuable for the groundwork of anti- metastatic therapy in the future.

\section{ACKNOWLEDGEMENTS}

This study was funded by the Fundamental Research Grant Scheme FRGS/1/2014/SKK01/UPM/02/6) from the Ministry of Education, Malaysia.

\section{REFERENCES}

Anand, P., Kunnumakkara, A.B., Newman, R.A. \& Aggarwal, B.B. 2007. Bioavailability of curcumin: Problems and promises. Molecular Pharmaceutics 4(6): 807-818.

Anders, C. \& Carey, L.A. 2008. Understanding and treating triple-negative breast cancer. Oncology (Williston Park) 22(11): 1233-1243.

Artym, V.V., Zhang, Y., Seillier-Moiseiwitsch, F., Yamada, K.M. \& Mueller, S.C. 2006. Dynamic interactions of cortactin and membrane type 1 matrix metalloproteinase at invadopodia: Defining the stages of invadopodia formation and function. Cancer Research 66(6): 3034-3043.

Azizah, A.M., Ibrahim, N.S. \& Abdullah, N.H. 2015. Malaysian National Cancer Registry Report 2007-2011. Putrajaya: Ministry of Health, Malaysia.

Balzer, E.M., Whipple, R.A., Thompson, K., Boggs, A.E., Slovic, J., Cho, E.H., Matrone, M.A., Yoneda, T., Mueller, S.C. \& Martin, S.S. 2010. c-Src differentially regulates the functions of microtentacles and invadopodia. Oncogene 29(48): 6402-6408.

Bergamo, A., Masi, A., Peacock, A.F.A., Habtemariam, A., Sadler, P.J. \& Sava, G. 2010. In vivo tumour and metastasis reduction and in vitro effects on invasion assays of the ruthenium RM175 and osmium AFAP51 organometallics in the mammary cancer model. Journal of Inorganic Biochemistry 104(1): 79-86

Bravo-Cordero, J.J., Hodgson, L. \& Condeelis, J. 2012. Directed cell invasion and migration during metastasis. Current Opinion in Cell Biology 24(2): 277-283.

Buccione, R., Orth, J.D. \& McNiven, M.A. 2004. Foot and mouth: Podosomes, invadopodia and circular dorsal ruffles. Nature Reviews Molecular Cell Biology 5(8): 647-657.

Chen, Q., Zheng, Y., Jiao, D., Chen, F., Hu, H., Wu, Y., Song, J., Yan, J., Wu, L. \& Lv, G. 2014. Curcumin inhibits lung cancer cell migration and invasion through Rac1-dependent signaling pathway. The Journal of Nutritional Biochemistry 25(2): 177-185.

Chen, Q.Y., Jiao, D.M., Yao, Q.H., Yan, J., Song, J., Chen, F.Y., Lu, G.H. \& Zhou, J.Y. 2012. Expression analysis of Cdc42 in lung cancer and modulation of its expression by curcumin in lung cancer cell lines. International Journal of Oncology 40(5): 1561-1568.

Chen, W.T. 1989. Proteolytic activity of specialized surface protrusions formed at rosette contact sites of transformed cells. Journal of Experimental Zoology 251(2): 167-185.
Cheung, K.J. \& Ewald, A.J. 2016. A collective route to metastasis: Seeding by tumor cell clusters. Science 352(6282): 167-169.

Chevalier, C., Collin, G., Descamps, S., Touaitahuata, H., Simon, V., Reymond, N., Fernandez, L., Milhiet, P.E., Georget, V., Urbach, S., Lasorsa, L., Orsetti, B., Boissière-Michot, F., Lopez-Crapez, E., Theillet, C., Roche, S. \& Benistant, C. 2016. TOM1L1 drives membrane delivery of MT1-MMP to promote ERBB2-induced breast cancer cell invasion. Nature Communications 7(1): 1-16.

Chhabra, E.S. \& Higgs, H.N. 2007. The many faces of actin: matching assembly factors with cellular structures. Nature Cell Biology 9(10): 1110-1121.

Chiu, T-L. \& Su, C-C. 2009. Curcumin inhibits proliferation and migration by increasing the $\mathrm{Bax}$ to $\mathrm{Bcl}-2$ ratio and decreasing NF-kBp65 expression in breast cancer MDA-MB-231 cells. International Journal of Molecular Medicine 23(4): 469-475.

Clark, E.S., Whigham, A.S., Yarbrough, W.G. \& Weaver, A.M. 2007. Cortactin is an essential regulator of matrix metalloproteinase secretion and extracellular matrix degradation in invadopodia. Cancer Research 67(9): 42274235 .

David-Pfeuty, T. \& Singer, S.J. 1980. Altered distributions of the cytoskeletal proteins vinculin and alpha-actinin in cultured fibroblasts transformed by Rous sarcoma virus. Proceedings of the National Academy of Sciences of the United States of America 77(11): 6687-6691.

Dent, R., Trudeau, M., Pritchard, K.I., Hanna, W.M., Kahn, H.K., Sawka, C.A., Lickley, L.A., Rawlinson, E., Sun, P. \& Narod, S.A. 2007. Triple-negative breast cancer: Clinical features and patterns of recurrence. Clinical Cancer Research 13(15): 4429-4434.

Di, G.H., Li, H.C., Shen, Z.Z. \& Shao, Z.M. 2003. Analysis of anti-proliferation of curcumin on human breast cancer cells and its mechanism. Zhonghua Yi Xue Za Zhi 83(20): 1764-1768.

Di Martino, J., Paysan, L., Gest, C., Lagrée, V., Juin, A., Saltel, F. \& Moreau, V 2014. Cdc42 and Tks5: A minimal and universal molecular signature for functional invadosomes. Cell Adhesion \& Migration 8(3): 280-292.

Díaz, B., Yuen, A., Iizuka, S., Higashiyama, S. \& Courtneidge, S.A. 2013. Notch increases the shedding of HB-EGF by ADAM12 to potentiate invadopodia formation in hypoxia. Journal of Cell Biology 201(2): 279-292.

Doyle, A.D., Petrie, R.J., Kutys, M.L. \& Yamada, K.M. 2013. Dimensions in cell migration. Current Opinion in Cell Biology 25(5): 642-649.

Egeblad, M. \& Werb, Z. 2002. New functions for the matrix metalloproteinases in cancer progression. Nature Reviews Cancer 2(3): 161-174.

Fu, H., Wu, R., Li, Y., Zhang, L., Tang, X., Tu, J., Zhou, W., Wang, J. \& Shou, Q. 2016. Safflower yellow prevents pulmonary metastasis of breast cancer by inhibiting tumor cell invadopodia. The American Journal of Chinese Medicine 44(7): 1491-1506.

Gligorijevic, B., Wyckoff, J., Yamaguchi, H., Wang, Y., Roussos, E.T. \& Condeelis, J. 2012. N-WASP-mediated invadopodium formation is involved in intravasation and lung metastasis of mammary tumors. Journal of Cell Science 125(3): 724734.

Gujam, F.J.A., Going, J.J., Mohammed, Z.M.A., Orange, C., Edwards, J. \& McMillan, D.C. 2014. Immunohistochemical 
detection improves the prognostic value of lymphatic and blood vessel invasion in primary ductal breast cancer. $B M C$ cancer 14(1): 676.

Gupta, S.C., Patchva, S., Koh, W. \& Aggarwal, B.B. 2012. Discovery of curcumin, a component of golden spice, and its miraculous biological activities. Clinical and Experimental Pharmacology and Physiology 39(3): 283-299.

Hall, A. 1998. Rho GTPases and the actin cytoskeleton. Science 279(5350): 509-514.

Hanahan, D. \& Weinberg, R.A. 2011. Hallmarks of cancer: The next generation. Cell 144(5): 646-674

Harun, S.N.A., Israf, D.A., Tham, C.L., Lam, K.W., Cheema, M.S. \& Hashim, N.F.M. 2018. The molecular targets and antiinvasive effects of 2,6-bis-(4-hydroxyl-3methoxybenzylidine) cyclohexanone or BHMC in MDA-MB-231 human breast cancer cells. Molecules 23(4): 865.

Hassan, Z.K. \& Daghestani, M.H. 2012. Curcumin effect on MMPs and TIMPs genes in a breast cancer cell line. Asian Pacific Journal of Cancer Prevention 13(7): 3259-3264.

Hoshino, D., Branch, K.M. \& Weaver, A.M. 2013. Signaling inputs to invadopodia and podosomes. Journal of Cell Science 126(14): 2979-2989.

Ichikawa, K. 2015. Synergistic effect of blocking cancer cell invasion revealed by computer simulations. Mathematical Biosciences and Engineering 12(6): 1189-1202.

Jiang, P., Enomoto, A. \& Takahashi, M. 2009. Cell biology of the movement of breast cancer cells: Intracellular signalling and the actin cytoskeleton. Cancer Letter 284(2): 122-130.

Koo, H.J., Shin, S., Choi, J.Y., Lee, K.H., Kim, B.T. \& Choe, Y.S. 2015. Introduction of methyl groups at $\mathrm{C} 2$ and $\mathrm{C} 6$ positions enhances the antiangiogenesis activity of curcumin. Scientific Reports 5: 14205.

Krausz, A.E., Adler, B.L., Cabral, V., Navati, M., Doerner, J., Charafeddine, R.A., Chandra, D., Liang, H., Gunther, L., Clendaniel, A., Harper, S., Friedman, J.M., Nosanchuk, J.D. \& Friedman, A.J. 2015. Curcumin-encapsulated nanoparticles as innovative antimicrobial and wound healing agent. Nanomedicine: Nanotechnology, Biology, and Medicine 11(1): 195-206.

Kuo, J.C., Han, X., Hsiao, C.T., Yates, J.R. \& Waterman, C.M. 2011. Analysis of the myosin-II-responsive focal adhesion proteome reveals a role for $\beta$-Pix in negative regulation of focal adhesion maturation. Nature Cell Biology 13(4): 383-395.

Langley, R.R. \& Fidler, I.J. 2011. The seed and soil hypothesis revisited - The role of tumorstroma interactions in metastasis to different organs. International Journal of Cancer 128(11): 2527-2535.

Lee, W.H., Loo, C.Y., Young, P.M., Rohanizadeh, R. \& Traini, D. 2016. Curcumin nanoparticles attenuate production of pro-inflammatory markers in lipopolysaccharide-induced macrophages. Pharmaceutical Research 33(2): 315-327.

Linder, S. \& Aepfelbacher, M. 2003. Podosomes: Adhesion hotspots of invasive cells. Trends in Cell Biology 13(7):376-385.

Liotta, L.A., Steeg, P.S. \& Stetler-Stevenson, W.G. 1991. Cancer metastasis and angiogenesis: An imbalance of positive and negative regulation. Cell 64(2): 327-336.

Lohmer, L.L., Kelley, L.C., Hagedorn, E.J. \& Sherwood, D.R. 2014. Invadopodia and basement membrane invasion in vivo. Cell Adhesion \& Migration 8(3): 246-255.

Mader, C.C., Oser, M., Magalhaes, M.A.O., Bravo-Cordero, J.J., Condeelis, J., Koleske, A.J. \& Gil-Henn, H. 2011. An EGFR-
Src-Arg-Cortactin pathway mediates functional maturation of invadopodia and breast cancer cell invasion. Cancer Research 71(5): 1730-1741.

Massagué, J., Batlle, E. \& Gomis, R.R. 2017. Understanding the molecular mechanisms driving metastasis. Molecular Oncology 11(1): 3-4.

Md Hashim, N.F., Nicholas, N.S., Dart, A.E., Kiriakidis, S., Paleolog, E. \& Wells, C.M. 2013. Hypoxia-induced invadopodia formation: A role for -PIX. Open Biology 3(6): 120159-120159.

Mendonsa, A.M., Na, T.Y. \& Gumbiner, B.M. 2018. E-cadherin in contact inhibition and cancer. Oncogene 37(35): 4769-4780.

Ming-Tatt, L., Khalivulla, S.I., Akhtar, M.N., Lajis, N., Perimal, E.K., Akira, A., Ali, D.I. \& Sulaiman, M.R. 2013. Antihyperalgesic effect of a benzilidine-cyclohexanone analogue on a mouse model of chronic constriction injury-induced neuropathic pain: Participation of the $\kappa$-Opioid receptor and KATP. Pharmacology Biochemistry and Behavior 114-115: 58-63.

Miyazawa, Y., Uekita, T., Ito, Y., Seiki, M., Yamaguchi, H. \& Sakai, R. 2013. CDCP1 regulates the function of MT1MMP and invadopodia-mediated invasion of cancer cells. Molecular Cancer Research 11(6): 628-637.

Murphy, D.A. \& Courtneidge, S.A. 2011. The 'ins' and 'outs' of podosomes and invadopodia: Characteristics, formation and function. Nature Reviews Molecular Cell Biology 12(7): 413-426.

Neil, J.R. \& Schiemann, W.P. 2008. Altered TAB1: IKK interaction promotes TGF- $\beta$-mediated NF- $\kappa \mathrm{B}$ activation during breast cancer progression. Cancer research 68(5): 1462-1470.

Orsetti, B., Nugoli, M., Cervera, N., Lasorsa, L., Chuchana, P., Ursule, L., Nguyen, C., Redon, R., Du Manoir, S., Rodriguez, C. \& Theillet, C. 2004. Genomic and expression profiling of chromosome 17 in breast cancer reveals complex patterns of alterations and novel candidate genes. Cancer Research 64(18): 6453-6460.

Paget, S. 1889. The distribution of secondary growths in cancer of the breast. The Lancet 133(3421): 571-573.

Pollard, T.D. \& Borisy, G.G. 2003. Cellular motility driven by assembly and disassembly of actin filaments. Cell 112(4): 453-465.

Poste, G. \& Fidler, I.J. 1980. The pathogenesis of cancer metastasis. Nature 283(5743): 139-146.

Razak, N.A., Akhtar, M.N., Abu, N., Ho, W.Y., Tan, S.W., Zareen, S., Taj-ud-din, S.N. bin, Long, K., Alitheen, N.B. \& Yeap, S.K. 2017. The in vivo anti-tumor effect of curcumin derivative $(2 \mathrm{E}\{\} ,6 \mathrm{E})-2\{$,$\} 6-bis(4-hydroxy-3-methoxybenzylidene)$ cyclohexanone (BHMC) on 4T1 breast cancer cells. RSC Advance 7(57): 36185-36192.

Revach, O.Y., Winograd-Katz, S.E., Samuels, Y. \& Geiger, B. 2016. The involvement of mutant Rac1 in the formation of invadopodia in cultured melanoma cells. Experimental Cell Research 343(1): 82-88.

Ridley, A.J. 2015. Rho GTPase signalling in cell migration Current Opinion in Cell Biology 36: 103-112.

Riggi, N., Aguet, M. \& Stamenkovic, I. 2018. Cancer metastasis: A reappraisal of its underlying mechanisms and their relevance to treatment. Annual Review of Pathology: Mechanisms of Disease 13: 117-140.

Sahai, E. 2005. Mechanisms of cancer cell invasion. Current Opinion in Genetics \& Development 15(1): 87-96. 
Schnoor, M., Stradal, T.E. \& Rottner, K. 2017. Cortactin: Cell functions of a multifaceted actin-binding protein. Trends in Cell Biology 28(2): 79-98.

Scolaro, C., Bergamo, A., Brescacin, L., Delfino, R., Cocchietto, M., Laurenczy, G., Geldbach, T.J., Sava, G. \& Dyson, P.J. 2005. In vitro and in vivo evaluation of ruthenium (II)- arene PTA complexes. Journal of Medicinal Chemistry 48(12): 4161-4171.

Scully, O.J., Bay, B.H., Yip, G. \& Yu, Y. 2012. Breast cancer metastasis. Cancer Genomics-Proteomics 9(5): 311-320.

Shao, Z.M., Shen, Z.Z., Liu, C.H., Sartippour, M.R., Go, V.L., Heber, D. \& Nguyen, M. 2002. Curcumin exerts multiple suppressive effects on human breast carcinoma cells. International Journal of Cancer 98(2): 234-240.

Shen, H.L., Liu, Q.J., Yang, P.Q. \& Tian, Y. 2015. Protein interactions of cortactin in relation to invadopodia formation in metastatic renal clear cell carcinoma. Tumor Biology 36(5): 3417-3422.

Smid, M., Wang, Y., Klijn, J.G.M., Sieuwerts, A.M., Zhang, Y., Atkins, D., Martens, J.W.M. \& Foekens, J.A. 2006. Genes associated with breast cancer metastatic to bone. Journal of Clinical Oncology 24(15): 2261-2267.

Steeg, P.S. 2016. Targeting metastasis. Nature Reviews Cancer 16(4): 201-218.

Sun, K., Duan, X., Cai, H., Liu, X., Yang, Y., Li, M., Zhang, X. \& Wang, J. 2016. Curcumin inhibits LPA-induced invasion by attenuating RhoA/ROCK/MMPs pathway in MCF7 breast cancer cells. Clinical and Experimental Medicine 16(1): 37-47.

Tang, D., Tao, D., Fang, Y., Deng, C., Xu, Q. \& Zhou, J. 2017. TNF-alpha promotes invasion and metastasis via NF-kappa B pathway in oral squamous cell carcinoma. Medical Science Monitor Basic Research 23: 141-149.

Tarone, G., Cirillo, D., Giancotti, F.G., Comoglio, P.M. \& Marchisio, P.C. 1985. Rous sarcoma virus-transformed fibroblasts adhere primarily at discrete protrusions of the ventral membrane called podosomes. Experimental Cell Research 159(1): 141-157.

Tham, C.L., Lam, K.W., Rajajendram, R., Cheah, Y.K., Sulaiman, M.R., Lajis, N.H., Kim, M.K. \& Israf, D.A. 2011. The effects of a synthetic curcuminoid analogue, 2,6-bis-(4hydroxyl-3-methoxybenzylidine)cyclohexanone on proinflammatory signaling pathways and CLP-induced lethal sepsis in mice. European Journal of Pharmacology 652(1-3): 136-144.

Tham, C.L., Liew, C.Y., Lam, K.W., Mohamad, A.S., Kim, M.K., Cheah, Y.K., Zakaria, Z.A., Sulaiman, M.R., Lajis, N.H. \& Israf, D.A. 2010. A synthetic curcuminoid derivative inhibits nitric oxide and proinflammatory cytokine synthesis. European Journal of Pharmacology 628(1-3): 247-254.
Tolde, O., Rösel, D., Veselý, P., Folk, P. \& Brábek, J. 2010. The structure of invadopodia in a complex 3D environment. European Journal of Cell Biology 89(9): 674-680.

Wang, S., Li, E., Gao, Y., Wang, Y., Guo, Z., He, J., Zhang, J., Gao, Z. \& Wang, Q. 2013. Study on invadopodia formation for lung carcinoma invasion with a microfluidic $3 \mathrm{D}$ culture device. PLoS ONE 8(2): e56448.

Wang, T., Liu, N.S., Seet, L.F. \& Hong, W. 2010. The emerging role of VHS domain containing Tom1, Tom1L1 and Tom1L2 in membrane trafficking. Traffic 11(9): 1119-1128.

Wang, Z., Liang, X., Cai, M. \& Du, G. 2016. Analysis of invadopodia formation in breast cancer cells. Methods in Molecular Biology 1406: 203-210.

Ward, J.D., Ha, J.H., Jayaraman, M. \& Dhanasekaran, D.N. 2015. LPA-mediated migration of ovarian cancer cells involves translocalization of Gai2to invadopodia and association with Src and B-pix. Cancer Letters 356(2): 382-391.

Weigelt, B., Peterse, J.L. \& Van't Veer, L.J. 2005. Breast cancer metastasis: Markers and models. Nature Reviews Cancer 5(8): 591-602.

Wu, Q., He, J., Mei, W., Zhang, Z., Wu, X. \& Sun, F. 2014. Arene ruthenium (II) complex, a potent inhibitor against proliferation, migration and invasion of breast cancer cells, reduces stress fibers, focal adhesions and invadopodia. Metallomics 6(12): 2204-2212.

Zambonin, A., Teti, A., Carano, A. \& Marchisio, P.C. 1988. The distribution of podosomes in osteoclasts cultured on bone laminae: Effect of retinol. Journal of Bone and Mineral Research 3(5): 517-523.

Siti Nor Aini Harun, Nurul Akmaryanti Abdullah, Noraina Muhamad Zakuan, Hafizah Abdul Hamid \& Nur Fariesha Md Hashim*

Department of Biomedical Sciences

Faculty of Medicine and Health Sciences

Universiti Putra Malaysia

43400 UPM Serdang, Selangor Darul Ehsan Malaysia

Muhammad Zulfadli Mehat

Department of Human Anatomy

Faculty of Medicine and Health Sciences

Universiti Putra Malaysia

43400 UPM Serdang, Selangor Darul Ehsan

Malaysia

*Correspondence author; email: nurfariesha@upm.edu.my

Received: 12 July 2019

Accepted: 11 February 2020 